\title{
XXIV. On the classification of vegetables
}

\section{Rev. Patrick Keith F.L.S.}

To cite this article: Rev. Patrick Keith F.L.S. (1837) XXIV. On the classification of vegetables , Philosophical Magazine Series 3, 10:59, 108-116, DOI: 10.1080/14786443708649090

To link to this article: http://dx.doi.org/10.1080/14786443708649090

册 Published online: 01 Jun 2009.

Submit your article to this journal 준

Џ Article views: 2

Q View related articles $₫$ 
108 The Rev. P. Keith on the Classification of Vegetables.

Hence

$$
\begin{aligned}
\mathrm{R}^{\prime \prime} & =\frac{\mathrm{Y}^{\mathrm{z}}}{\mathrm{R}} \\
\mathrm{f}^{\prime} & =-\frac{\mathrm{Y} \mathrm{X}}{\mathrm{R}} .
\end{aligned}
$$

Compounding now the four forces $\rho, \rho^{\prime}, R^{\prime}, R^{\prime \prime}$, the first two destroy each other, the latter two give a sum; that is,

$$
\mathbf{R}=\mathbf{R}^{\prime}+\mathrm{R}^{\prime \prime}=\frac{\mathrm{X}^{2}+\mathrm{Y}^{2}}{\mathrm{R}} \text { or } \mathrm{R}^{2}=\mathrm{X}^{2}+\mathrm{Y}^{3} \text {. }
$$

Having proved that $\frac{Y}{X}=\tan (\theta)$ and $R^{*}=X^{2}+Y^{2}$, we easily obtain $\mathbf{X}=\mathbf{R} \cos \theta, \mathbf{Y}=\mathbf{R} \sin \theta$, which contain the principles of the composition and decomposition of any forces acting on a plane upon one point.

2, Bateman's Buildings, Soho, Dec. 23, 1836.

XXIV. On the Classification of Vegetables. By the Rev. Patrick Keith, F.L.S.

[Continued from p. 42, and concluded.]

$\mathbf{O}$ 'THERS have innovated upon Jussieu's nomenclature and general plan of arrangement, but it may be doubted whether they have in this respect improved the system. We will specify only two examples.

I. M. DeCandolle, Professor of Botany at Geneva, an acute and skilful systematist, exhibits the first example of innovation. In his Théorie Elémentaire and Prodromus, he substitutes the term Exogenæ in place of Dicotyledons, and the term Endogenæ in the place of Monocotyledons and Acotyledons; but we can see no advantage that is gained by the substitution. MM. Desfontaines and Daubenton had already shown that Dicotyledonous plants are exogenous, and Monocotyledonous plants endogenous, and Jussieu was well enough aware of the fact. The new terms, we admit, were not yet imposed; but if exogenous and endogenous are respectively identical in their extent, with Dicotyledonous plants on the one hand and with Monocotyledonous plants on the other, whence could the advantage of the substitution cone? And if you extend the meaning of endogenous so as to make it include Acotyledonous plants also, we question the legitimacy of the extension, and contend that their endogeneity is not at all of the same character with that of the Monocotyledous. Besides, the change of terms leaves the affair of method precisely where it was, while it has the effect of keeping Jussieu and his di- 
The Rev. P. Keith on the Classification of Vegetables. 109

visions too much in the background, as well as of giving room for the remark that the principles of the system are departed from. It is enough if the novel terms are introduced to the aid and illustration of the terms of Jussieu, but not to their entire exclusion. Neither do the names imposed upon the minor divisions seem to us to be any improvement. In what respect is thalamifloræ better than hypopetalæ; or calycifloræ than peripetalæ or epipetalæ? If neither one set of terms nor the other is imposed in strict conformity to the anatomical structure of flowers, why exclude one term that is faulty merely to make room for the introduction of another term that is faulty also? It may be true that the stamens and corolla have always the same insertion; it may be true that, in strictness of anatomical speech, their real insertion is always on the torus, but as botanical writers seem satisfied to describe them by their apparent insertion, we are of opinion that, unless some very obvious advantage were to follow from it, the nomenclature and divisions of Jussieu ought not to be disturbed. Finally, the division of Acotyledonous plants into Cryptogama and Cellulares does not seem to us to be a sufficiently scientific distribution of the group, because the Cellulares are still, in fact, Cryptogamous, as well as the Cryptogamæ themselves. But his Dichlamydeæ and Monochlamydeæ, and Achlamydeæ, we regard as improvements, as affording a convenient ground of subdivision, and imposing names upon distinctions involved, though not designated by individual terms in the arrangements of Jussieu.

II. A learned Professor of Botany among ourselves, of high talent and reputation, exhibits the second example of innovation. In his Introduction to the Natural System of Botany he sets out with "dividing vegetables into two grand groups, which he calls classes, the Vasculares and the Cellulares, or flowering and flowerless plants. The terms vascular and cellular stand sufficiently in opposition to one another to form the ground of a legitimate division; but the feature upon which they rest is not more important than that of cotyledons, or the want of them, and gives them, consequently, no apparent claim to supersede the terms of Jussieu. Besides, the terms employed by the Professor are, perhaps, not altogether so correctly descriptive of their respective groups as those employed by Jussieu. The former are of the same extent with cotyledonous plants, and the latter are presumed to be of the same extent with acotyledonous plants. But it is very well known that this is not the fact, as will appear from the following subdivisions into which the Cellulares are distributed by the Professor himself. 1st, The Vasculares are subdivided into the 


\section{The Rev. P. Keith on the Classification of l'egetables.}

Exogenæ and Endogenæ of M. DeCandolle,-terms which are substituted in place of the Dicotyledones and Monocotyledones of Jussieu, though we confess that we cannot see the utility of the substitution. The Exogenæ are next divided into Angiospermæe and Gymnospermx. The former seems to be of a dimension too unwieldy, as containing the polypetalous, apetalous, and diclinous plants of Jussieu, in no less than 165 orders, together with the monopetalæ, in 61 orders more; while the latter scems to be of a dimension too small, as containing only 2 orders, making it nearly the same thing in practice as if they were all angiospermous still; so that the peculiarities which the subdivision involves, thongh important in themselves, and founded undoubtedly in nature, do not seem to us to be of any great utility as forming the ground of a systematic arrangement, - at least, without having the krger subdivisions subdivided again, into a sufficient number of groups still smaller. The two main divisions of the Exogenx are called tribes, and yet the orders belonging to them are called tribes also. If this is a fanlt it is one that admits of an easy remedy, which, we think, the term family would furnish. The Endogenæe are subdivided into petaloidew with minor groups, and glumacex, a subdivision which presents to our notice nothing exceptionable. 2nd, The Cellulares are subdivided into Filicoider, Muscoider, and Aphyllæ, which might be a good enough division of the class provided it went by the name of Acotyledonous. But as the Cellulares are presumed to have no vascular system, we do not see how they can be legitimately made to include the Filicoider, the very diagnosis of which is that they are "flowerless plants, with a stem, having a vascular systcm and distinct leaves*." The Vasculares are the flowering plants, the Cellulares are the flowerless plants. The antithesis is good in fact, but it can scarcely be said to be good in expression. Flowering and flowerless are not so happily opposed to one another as powertul and power-less are, that is, the participle and the adjective, owing to their grammatical peculiarities, do not form a nent or laudable contrast. We admit that this want of systematic symmetry is but a mere trifle after all, though it ought not to have occurred in the work in question. To evade the objection arising from the vascularity of many of the Cellulares, it has been said that they are furnished merely with ducts, but not with spiral tubes. This may be all quite true, yet what are ducts but vessels?

We do not pretend to give advice to these able and eminent botanits, knowing that nothing short of the experience

* Introduction to Nat. System, p.310. 
The Rev. P. Keith on the Classification of Vegetables. 111

of the most profound adept is sufficient to qualify or to entitle any one to do so; neither do we expect from our speculative deinonstrations a result subversive of their practical arrangements. We merely claim the privilege of expressing and recording our sentiments, and of stating what seems to us to be exceptionable in the above novel method; or, at the least, not calculated to facilitate the study of the natural system, or to improve the method of Jussieu, which stands in need of no violent inıovations to give it in appearance the preeminence which it possesses in reality. It requires merely a drawing out of the resources which it has within itself, or the addition of such supplementary distinctions as the progress of botanical knowledge may have rendered necessary. In defence of innovations, it has been said that the system, though altered, is still but the system of Jussieu after all. True; for as there is but one system that is natural, and that system Jussieu's, botanists cannot conjure up a new one at their pleasure. "Other foundation can no man lay than that is laid,"-though he may disguise the old one, and build upon it a totally different structure, like Thunberg and Withering in their artificial arrangements. They counted stamens and pistils as did their great master Linneus, but they mutilated his system and substituted one of their own in its room.

But although we do not approve of the change of nomenclature, or of the innovations upon system introduced, whether by $\mathrm{M}$. DeCundolle or by Dr. Lindley, yet we are very far from wishing to depreciate the merit of their respective works; -works exhibiting such abundant proofs of extensive research, of accurate discrinination, and of just and logical deduction in the tracing of natural affinities, as will enable their respective authors to maintain that high station in the scale of botanical eminence which they had previously reached, and will doubtless secure to them a lasting reputation. If there should be a difficulty in unlocking Dr. Lindley's orders, even with the help of his analytical key, it is to be recollected that Dr. Lindley has never once attempted to disguise or to palliate difficulties, but rather to impress upon the mind of his reader the absolute necessity of unremitted exertion.

Nil sine magno

Vita labore dedit mortalibus.-Horace, Sat. 9, Lib.I.

His Introduction may not be adapted to the desultory application of the sciolist or trifler, but it will be found to be a very valuable present to the patient and indefatigable student who is content to encounter difficulties, and willing to obtain knowledge at the expense of labour.

If we were called upon to say how it is at all practicable to 


\section{The Rev. P. Keith on the Classification of Vegetables.}

adapt the system of Jussieu to the present state of botanical knowledge without innovating upon its principles, in external appearance at least, our reply would be, that availing ourselves of whatever we may find in the works of the above-mentioned authors, or of others, calculated to illustrate the character of the groups, or to give perspicuity to the arrangements of Jussieu, and retaining not merely the foundation but the identical structure which he reared upon it, we would venture to add to it a trifle more of extension, or of filling up, in the style and manner, as much as may be, of the original edifice, that the masterly traits of the band of the founder may never be lost sight of. It will be seen that this adaptation can descend no lower than to the distribution of classes. The orders and their arrangement will be continually changing as long as there shall remain new plants to be collected or new affinities to be discovered, but we do not see the necessity of any violent alteration in the circumscribing of the larger groups. All that we regard as necessary is comprised in the following tabular sketch, giving, as we fancy, a neatness of outline to the higher divisions of the system, by the formal introduction of a very few distinctions that were either implied in it from the beginning or rendered necessary by the progress of analytical research.

\section{Vegetables.}

Group I. COTYLEDONOUS PLANTS.-Vascular with spiral tubes;-phænogamous, - bisexual, - angiospermous.

Divis. I. Dicotyledons,-Growth exogenous,-circumferential.

Subd. I. Dichlamydlex.-Floral envelope double,-a calyx and corolla.

Sect. I. Polypetalous.

Class I. Hypopetalæ.

II. Peripetalæ.

III. Epipetalæ.

Sect. II. Monopetalous.

Class IV. Hypocorollæ.

V. Pericorollæ.

VI. Epicorollæ.

1. Synantheræ.

2. Corisantheræ.

Subd. II. Monochlamydece.-Floral envelope single, - a perianth or presumed calyx.

Sect. I. Apetalous.

Class VII. Hypostaminez. 
The Rev, P. Keith on the Classification of Vegetables. 113

VIII. Peristaminea.

IX. Epistaminex.

Sect. II. Anomalons.

Class X. Diclines.

1. Angiosperma.

2. Gymnospermæ.

Divis. II. Monocotyledons.-Growth endogenous,-central. Floral envelope a perianth, often in two rows; sepaloid, petaloid, or glumaceous.

Class XI. Monohypogynæ.

XII. Monoperigynæ.

XIII. Monoepigynæ.

Group II. ACOTYLEDONOUS PLANTS, - Cellular,

or, if vascular, without spiral tubes?-Cryptogamous.

Class XIV. Ductulosæ. -Cellular, with interspersed ducts,-seminiferous.

XV. Eductulosa. - Wholly cellular;-gemmiferous.

Thus the whole of the vegetable kingdom is clivided into two grand groups, without any sacrifice of the technical language of Jussieu. For although his system does not actually exhibit a division into Cotyledonous and Acotyledonous plants, yet it evidently and essentially involves that distinction. Hence the introduction of the former term is only the completing of the contrast which was already implied in the use of the latter. We have thought it right to put the group designated by the positive term first, because the student cannot be supposed to know well what is meant by an acotyledonous plant till he has already found out what is meant by a cotyledonous one; and although the term acotyledonons is negative in its composition, yet the character which it points out to the learner is positive, namely, that of the want or absence of cotyledons; so that the division is legitimate in whatever aspect you survey it. But we do not rest content merely with a correct antithesis. We avail ourselves of all the lights, old and new, that have been thrown upon either group. In the former we recognise its vascular, its phænogamous, its bisexual, and its angiospermous characters; and in the latter, its cellular, but partially vascular and cryptogamous characters. We accept them as auxiliaries illustrative of the respective groups, but we do not discard the old terms of Jussieu merely that we may use them as synonyms to new ones of our own.

The first grand group Jussieu distributed into two divisions, dicotyledonous and monocotyledonous-divisions that are well contrasted and cannot be improved. All that we add

Third Scries. Vol. 10. No. 59. Feb. 1837. 


\section{The Rev. P. Keith on the Classification of Vegetables.}

is merely their exogenous and endogenous characters re.spectively.

The division of the Dicotyledons we subdivide into Dichlamydeæ and Monochlamydea, terms invented by DeCandolle, but not introducing any new principle that was not already to be found in the system, and in full and actual operation. For although the terms were not there, the things signified by them were there, and were made available to the purposes of arrangement, though not designated by individual names. The forner term is equivalent to the double envelope of calyx and corolla, and the latter to the single envelope or perianth. They are all exogenous.

The division of the Monocotyledons Jussieu did not subdivide into any minor groups, and neither do we. We notice merely the leading peculiarities of the perianth. They are all endogenous.

In the whole of the above divisions, or subdivisions, the classes are uniformly founded on the mode of the insertion of the stamens, as being hypogynous, perigynous, or epigynous. For although a novice might fancy that the principle of arrangement changes with the change of termination in the names that have been imposed upon the classes, yet the more experienced botanist knows that the origin of the stamens and corolla is uniformly and universally the same, and that whatever is predicable of the one in that respect, is predicable also of the other; and although the introduction of these distinctions, at least in the circumscribing of classes, has been denounced as being wholly and essentially artificial, as well as utterly and absolutely extravagant, on the score of its exhibiting a want of due oeconomy in the husbanding of resources, and an improvident expenditure of botanical ammunition that might have been rendered available in the construction of orders and of genera ${ }^{*}$, yet this want of due ceconomy is altogether imaginary. There is an abundance of characters remaining for the constructing of orders and of genera, as resulting from other and important peculiarities discoverable in the form, structure, or position of the stamens, pistils, ovary and ovula, fruit, seed, embryo, or from additional and similar peculiarities discovernble in other parts of the flower or plant. Hence the distinctions founded on the mode of issertion, instead of being an objection to the method of Jussieu, are only a proof of its excellence, in the facility which they give to investigation and in their applicability to the whole of the grand group of cotyledonous plants, whether dicotyledonous or mo-

* Roscoe on Arrangements, Linn. Trans., vol. xi. part I. [Or Phil. Mag. and Annals, N. S., vol. vii.] 
nocotyledonous, dichlamydeous or monochlamydeous, polypetalous, monopetalous, or apetalous; so that by retaining the terms and divisions of Jussieu, we are, as it were, always in company with him, or meeting with him at every turn. Hence also the plan of procedure and the inquiries to be made by the student are always the same in all the divisions of the group. Is the plant cotyledonous or acotyledonous; is it dicotyledonous or monocotyledonous; is its floral envelope single or double; is the flower polypetalous, monopetalous, apetalous, or anomalous; are the stamens hypogynous, perigynous, or epigynous? This analysis brings him down to the several classes of the first grand group, which, from their number, are prevented from being surcharged with too many tribes or families. When botanists are prepared to introduce classes founded upon the principle suggested by Dr. Brown in his Botany of Congo and of Terra Australis, that is, the principle of combining into an aggregate group, to be called a class, such orders as are very closely allied, not merely by a single trait, but by the sum of their affinities, enabling us to dispense with the use of empirical characters entirely, then it will be time enough to discard the classes of Jussieu. The objections to which they are liable apply with equal force to the divisions by which they have been superseded in the works of the above systematists; all of them being clogged with anomalies that will puzzle the learner and impede him in his career, let him embrace what system he will.

The second grand group Jussien did not divide into any minor groups, but introduced merely as a single class. Yet there is an evident demand for such a division, both from the number of species which the group contains and from the peculiarities of structure which several of its tribes display. We adopt a division founded upon anatomical principles, and indicated by features sufficiently obvious, as well as designated by terms which, though novel, are peculiarly appropriate, namely, the Ductulose, or cellular plants with ducts, but without spiral tubes, as it is said; and the Eductulosce, or plants wholly cellular; the former propagated, perhaps, by seeds, the latter by gems or sporules. The above terms appear to have been originally introduced by Mr. Arnott, of Edinburgh, and seem to us to be quite unexceptionable *. The groups which they designate we would erect into classes, the number being still 15; for though we have thus split one of Jussieu's classes in to two, for reasons that to us seem valid, we have elsewhere run two of his classes into one-the Epicorollæ synantheræ, and Epicorollæ corisantheræ, for reasons that seem

* Encyc. Brit., art. Botany.

Q2 
equally valid, by reducing the peculiarities to sections. Beyond this our remarks do not extend. It is the part of the experienced and practical botanist to reduce classes to orders, or to suborders, if necessary, and to construct their diagnosis; or rather, perhaps, by reversing the process and advancing in the line of ascent, to reduce orders or suborders to classes; and to the experienced and practical botanist we are content to commit the task.

P. КеIтн.

Charing, Kent, Feb. 15, 1835.

XXV. Researches in Organic Chemistry.-First Series. Contributions to the History of Pyroxylic Spirit and of its derived Combinations. By Robert J. Kane, M.D., M.R.I.A.

[Continued from p. 51, and concluded.]

Of the Products of the Oxidation of Pyroxylic Spirit by Sulphuric Acid and Black Oxide of Manganese.

W ${ }^{H E N}$ sulphuric acid, black oxide of manganese, and pyroxylic spirit are brought into contact, the action which ensues is very violent, and there is so much effervescence that unless the retort be taken very large in proportion to the quantity of materials used there is great danger of its boiling over. By previously diluting the sulphuric acid with water, allowing the mixture to cool before adding thereto the black oxide of manganese and sulphuric acid, this can be to a great extent avoided, and the quantity of product is also by this means considerably increased.

The proportions found most advantageous were two ounces of pyroxylic spirit, three of sulphuric acid and three of water, and two of black oxide of manganese. The manganese and pyroxylic spirit having been first put into the retort and afterwards the diluted and cold sulphuric acid added, the whole is to be very gently heated in a water-bath, and as soon as the mass commences to froth, the fire should be withdrawn, in order to prevent the temperature of the water from rising too high, in which case the mixture is liable to boil over. Once commenced, the distillation goes on almost of itself; as the ebullition moderates the temperature can be again raised, and the distillation continued as long as any fluid comes over, by the water-bath. If the water- be then replaced by a sand-bath and the receiver changed, a liquor can be obtained which is a dilute formic acid.

The product obtained by distillation in the water-bath is very heterogeneous; it must be rectified in the.water-bath. It begins to boil under $40^{\circ}$ centigrade, and the boiling point gra- 